\title{
РОЗВИТОК ПРАКТИЧНО-ОРІЄНТОВАНОГО ТА СИМУЛЯЦИЙНОГО НАВЧАННЯ В ТЕРНОПІЛЬСЬКОМУ ДЕРЖАВНОМУ МЕДИЧНОМУ УНІВЕРСИТЕТІ ІМЕНІ І. Я. ГОРБАЧЕВСЬКОГО
}

\author{
М. М. Корда, А. Г. Шульгай, А. А. Гудима, С. Й. Запорожан \\ ДВНЗ “Тернопільський державний медичний університет імені I. Я. Горбачевського \\ мОЗ України”

\section{DEVELOPMENT OF PRACTICE-ORIENTED AND SIMULATION UNIVERSITY} \\ TRAINING AT I. HORBACHEVSKY TERNOPIL STATE MEDICAL \\ M. M. Korda, A. H. Shulhai, A. A. Hudyma, S. Y. Zaporozhan \\ I. Horbachevsky Ternopil State Medical University
}

\begin{abstract}
У статті висвітлено основні етапи впровадження практично-орієнтованого та симуляційного навчання у Тернопільському державному медичному університеті. Показано формування та структуру навчально-практичного центру симуляційного навчання, його роль у підготовці фахівців.

The main stages of implementation of practice-oriented and simulation training at Ternopil State Medical University are presented in this article. Establishing and structure of the Practical Training Centre of Simulation Training and its influence on professionals' training are specified.
\end{abstract}

Вступ. Розвиток сучасної медичної освіти в Україні, перехід на нові стандарти вищої освіти, основані на компетентнісному підході до організації освітнього процесу, вимагають удосконалення методик навчання. Здатність випускника успішно здійснювати професійну діяльність повинна грунтуватися на динамічній комбінації знань, вмінь і практичних навичок, способів мислення, професійних якостей. Стрімкий розвиток науково-технічного прогресу, використання у практичній діяльності лікаря сучасних інноваційних приладів, обладнання, вимагає акцентування компетентностей підготовки лікарів на практичному здобутті навиків та алгоритмів при діагностиці та лікуванні різних патологій. При цьому важливим залишається запровадження наскрізного практично-орієнтованого навчання при вивченні дисциплін природничо-наукової та професійної підготовки.

Внесення до стандартів вищої освіти обов’язкового засвоєння практичних навичок вимагає проведення ряду організаційних заходів з їх контролю. У багатьох країнах Європи та США і Канади введе-

( М. М. Корда, А. Г. Шульгай, А. А. Гудима, С. Й. Запорожан но обов’ язковий об’єктивний структурований клінічний іспит. При цьому складання даного іспиту є обов'язковою складовою допуску до майбутньої професійної діяльності.

Сучасна охорона здоров’я характеризується стрімким ростом високотехнологічних засобів діагностики, лікування, профілактики і реабілітації пацієнтів. Кількість практичних навичок, які повинен опанувати лікар, значно зросла. На сьогодні не завжди можливим є забезпечення навчального процесу, відпрацювання обов'язкових практичних навичок й алгоритмів надання невідкладної та екстреної допомоги, тематичними пацієнтами та хворими з відповідними невідкладними станами. Окрім цього, у зв'язку з наближенням до запровадження страхової медицини, права пацієнта вимагають їхньої згоди на виконання тих чи інших дій, з точки зору освітнього процесу, з кожним роком все більш актуальними стають правові аспекти навчання студентів біля ліжка хворого тактичних навичок. Зустрічається багато випадків незгоди пацієнтів на проведення обстеження їх студентами, виконання студентами маніпуляцій, оперативних прийомів. Все це в цілому породжує проблему по- 
шуку нових засобів для навчання студентів, серед яких, як показує світовий досвід, перспективним є симуляційне навчання.

Передумовами впровадження симуляційного навчання стало стрімке впровадження великої кількості віртуальних технологій у різні сфери діяльності людини. У системі вітчизняної охорони здоров’я, в числі іншого, з’явилися і широко впроваджуються різноманітні фантоми, моделі, муляжі, тренажери, віртуальні симулятори та інші технічні засоби навчання, що дозволяють з тим чи іншим ступенем вірогідності моделювати процеси, ситуації та інші аспекти професійної діяльності медичних працівників.

Сучасний стан розробки та виготовлення манекенів, а також приладів для відпрацювання алгоритмів виконання практичних навичок повністю забезпечує тими чи іншими симуляторами та манекенами для їх відпрацювання до максимального відтворення в реальних умовах. При цьому сучасні манекени дозволяють моделювати різні ситуації. У зв’язку з цим доцільним є у підготовці фахівців галузі знань “Охорона здоров’я” запроваджувати наскрізною програмою практично-орієнтоване навчання.

Основна частина. Для покращення практичної підготовки на додипломному рівні, забезпечення якості підготовки фахівців у Тернопільському державному медичному університеті прийнято рішення про запровадження ряду освітніх технологій щодо практично-орієнтованого навчання. При цьому, вже починаючи з першого курсу, при вивченні дисциплін природничо-наукової підготовки розпочинається знайомство студентів із застосуванням у діагностичному та лікувальному процесах того чи іншого обладнання, вивчення принципів, які лежать в основі роботи медичних приладів. Так, в основу вивчення медичної фізики покладено завдання на основі фізичних явищ вивчити функціонування біомеханічного, електромагнітного та оптичного медичного обладнання, а також функціонування апаратних медичних комплексів. Отримані студентами теоретичні та практичні знання дозволять сформувати фахові компетентності в галузі медичної фізики й загальні компетентності з метою їх подальшого використання при вивченні професійноорієнтованих програм. В основу покладено навчання студентів при вивченні як самого медичного обладнання, так і вивчення його основних блоків та механізмів дії за допомогою віртуальних навчаль- них програм. До кожного практичного заняття 3 медичної фізики створено віртуальні навчальні програми працівниками кафедри медичної фізики Тернопільського медичного університету спільно 3 інженерами-програмістами відділу інформаційних технологій. Всього з даної дисципліни в освітньому процесі використовується 51 навчальна віртуальна програма з медичної фізики.

У вивченні студентами анатомії людини, топографії ділянок та органів запроваджено поряд із препаруванням фізичних тіл на кожному занятті одночасне вивчення топографії органів і їх співвідношення на комп'ютерних томограмах, контрастних та оглядових рентгенограмах у нормі. 3 цією метою на кафедрі створено та постійно оновлюється банк комп’ютерних томограм та рентгенограм тіла людини на електронних і плівкових носіях, які використовуються під час проведення практичних занять. Під час практичних занять широко використовується віртуальне препарування, яке налагоджено у кожній навчальній кімнаті, а також віртуальні навчальні програми, розроблені співробітниками кафедри.

На кафедрі медичної біохімії створено тематичні навчальні аудиторії, ензимодіагностики, гормональних досліджень, білкового обміну, ліпідного обміну, вуглеводного обміну.

На кафедрі нормальної фізіології працює 6 навчальних лабораторій: $з$ функціональної діагностики системи кровообігу, з функціональної діагностики системи крові, з функціональної діагностики системи дихання, з функціональної діагностики сенсорних систем, з функціональної діагностики нервової та ендокринної систем, з функціональної діагностики систем травлення і виділення, у яких проводяться відповідно до наявного обладнання тематичні практичні заняття. При цьому відбувається робота студентів із більшістю приладів, які використовуються у функціональній діагностиці. Це є робота 3 комп’ютерним периграфом, аудіотестерами, електронним аномалоскопом, автоматичним рефрактометром, електроофтальмоскопом, електронними спірографами, ацидогастрометрами та ін. Студенти навчаються знімати та читати електрокардіограму здорової людини, визначати за нею частоту пульсу і особливості ритму, вивчають і розшифровують спірограми, засвоюють методику проведення велоергометрії тощо.

Для покращення засвоєння студентами практичних навичок $з$ діагностики в університеті створено 
кафедру клініко-лабораторної діагностики і кафедру функціональної діагностики та клінічної патофізіології. Кафедри оснащено сучасним діагностичним обладнанням. Кафедрами розроблено навчальні програми, які базуються на набутті практичних навичок при безпосередній роботі з клінічним матеріалом, з використанням сучасних біохімічних та імунологічних аналізаторів. Студенти аналізують показники, отримані при різних видах патологічних станів, функціональному дослідженні органів та систем за допомогою сучасних апаратів, і засвоюють методики, які використовуються у лікувальному та діагностичному процесі.

Клінічною базою кафедри функціональної діагностики є відділення функціональної діагностики університетської лікарні, а кафедри клініколабораторної діагностики - міжкафедральна клінічна лабораторія та клінічна лабораторія університетської лікарні.

3 метою контролю засвоєння студентами практичних навичок, визначених стандартами вищої освіти за кожною спеціальністю, введені матрикули практичних навичок, які є обов'язковими для опанування студентами протягом навчального року.

Рівень оволодіння практичною навичкою, включеною у матрикул, є обов'язковим. Після завершення навчального року і зарахування усіх практичних навичок матрикул здається у деканат і зберігається в архіві, як і інші документи про успішність студентів. Студенти, які не засвоїли практичних навичок, визначених у матрикулі, вважаються такими, що не виконали навчальної програми та навчального плану.

Окремим видом контролю за опануванням студентами практичних навичок є об'єктивний структурований клінічний іспит (ОСКI). Цей вид контролю в Тернопільському державному медичному університеті імені І. Я. Горбачевського введено у 2009 р. При цьому ОСКІ для студентів є допуском до проведення семестрового підсумкового контролю. Семирічна практика ОСКІ довела доцільність його проведення, та підтвердила значно вищий рівень засвоєння практичних навичок.

Застосування при проведенні контролю практичних навичок під час ОСКI “віртуальних пацієнтів" та манекенів і тренажерів забезпечує для студентів всі умови для демонстрації своїх вмінь у реальних умовах змодельованої ситуації. Під час іспиту студент повинен продемонструвати 12 практичних навичок з різних дисциплін, тобто виконати 12 різ- них завдань. На виконання кожного завдання відводиться певний час, якщо студент не вкладається у ліміт часу - він повинен перейти до наступного завдання. Під час проведення іспиту студент повинен уважно прочитати завдання і зробити відповідні дії, що відповідають стандартному алгоритму виконання навички. Екзаменатор навіть не спілкується зі студентом, він лише оцінює адекватність дій і виставляє оцінку.

У ТДМУ приділяють значну увагу симуляційному навчанню. Перша віртуальна клініка була створена у 2003 р. на базі Навчально-наукового інституту медсестринства. Для навчання медичних сестер створено віртуальну операційну.

Для забезпечення викладання дисципліни "Екстрена та невідкладна медична допомога” опорною кафедрою, якою є кафедра ТДМУ, було складено список практичних навичок та перелік сучасних засобів для навчання. Для забезпечення освітнього процесу було створено навчально-практичний центр, який оснащено сучасними манекенами. Відпрацювання навичок відбувається в умовах, максимально наближених до реальних клінічних ситуацій.

Структура навчально-практичного центру симуляційного навчання включає ряд тематичних кабінетів симуляційного навчання, кабінети викладачів, завідувача центру.

Кабінет для відпрацювання навичок серцеволегеневої реанімації оснащений повноростовими манекенами для відпрацювання базових реанімаційних заходів та кваліфікованих заходів реанімації з імітацією серцевих ритмів і можливістю застосування автоматичного або ручного дефібрилятора. Окремо також $є$ манекени для відпрацювання навичок прохідності дихальних шляхів, штучної вентиляції легень різними методами, а також манекени для відпрацювання навичок серцево-легеневої та мозкової реанімації.

Кабінет симуляційного навчання в педіатрії відтворює фрагменти палати педіатричного відділення із доглядом за новонародженим у кювезі, догляду за дітьми різного віку та їх фізикального обстеження. Окрім того, кабінет обладнаний манекеном для проведення реанімаційних заходів у педіатрії: серцево-легеневої реанімації, відновлення прохідності дихальних шляхів, дефібриляції та електрокардіографічного контролю.

Кабінет симуляційного навчання у внутрішній медицині оснащений манекенами для симуляцій- 
ного навчання догляду за хворими, манекенами для аускультації при різних патологіях органів дихання, серцевих шумів. Також кабінет містить манекен, що імітує порушення серцевого ритму із кардіомоніторингом, який дає можливість інструктору дистанційно управляти та змінювати серцеві ритми.

Кабінет симуляційного навчання з хірургії оснащений тренажерами з малоінвазивної та ендоскопічної хірургії, фрагментами операційної, тренажерами для відпрацювання хірургічної техніки роз'єднання та з'єднання тканин, оперативних прийомів. Для відпрацювання техніки проведення ендоскопічних малоінвазивних операційних втручань на експериментальних тваринах (в’єтнамських свинях) створено в межах віварію операційну, яку оснащено необхідним обладнанням та лапароскопічною стійкою.

\section{Список літератури}

1. Закон України “Про вищу освіту” від 01.07.2014 p. № 1556-VII. - Режим доступу : http://zakon2.rada.gov.ua/ laws/show/1556-18.

2. Корда М. М. Шляхи імплементації Закону України “Про вищу освіту” в Тернопільському державному
Кабінет симуляційного навчання в акушерстві та гінекології включає манекени для симуляції родової діяльності, реанімації та догляду новонародженого, гінекологічні манекени.

Кабінет тактичної медицини симулює умови, максимально наближені до польових, забезпечує можливості відпрацювання навичок із домедичної допомоги в екстремальних умовах.

Перспективний розвиток симуляційного навчання у підготовці висококваліфікованих фахівців направлений на відпрацювання не тільки окремих навичок, але і навчання алгоритмів роботи в команді.

Висновок. Впровадження практично-орієнтованого та симуляційного навчання дозволяє підготувати якісно нового фахівця, який відповідатиме сучасним вимогам стандартів вищої освіти.

медичному університеті / М. М. Корда, А. Г. Шульгай, I. М. Кліщ // Медична освіта. - 2015. - № 2. - С. 3439.

Отримано 04.04.16 